\title{
Agronomic Performance and Bread Making Quality of Advanced Bread Wheat (Triticum aestivum) Lines Grown in Eastern Oromia, Ethiopia
}

\author{
Ermias Estifanos $^{1}$, Geremew Bultosa ${ }^{2^{*}}$, Habtamu Zelleke ${ }^{3}$ and Harjit Singh $^{3}$ \\ ${ }^{1}$ Agricultural Technical and Vocational Education Training College, P O Box 242, Assosa, Ethiopia, E-mail: \\ ermiasestifo@yahoo.com \\ ${ }^{2}$ Department of Food Science and Post Harvest Technology, P O Box 22, Haramaya University Campus, Ethiopia \\ ${ }^{3}$ Department of Plant Science, P O Box 219, Haramaya University, Ethiopia
}

\begin{abstract}
Twenty bread wheat lines selected on the basis of their average grain protein content and yield were evaluated for six agronomic and eight baking quality traits associated with bread-making quality. All the lines were grown in randomly complete block design at two locations in Eastern Oromia, Ethiopia; namely, Haramaya and Hirna in 2004/2005. Most of the quality traits had higher genotypic and phenotypic coefficients of variability than yield at both locations. Grain protein content and yield related traits had low variabilities. Three bread wheat lines (RBC/HAR800, HAR3740 and Pavon76) superior with respect to bread making quality parameters and yielding ability of above and around the grand mean were identified. These lines could be useful as donor parents for bread making quality in bread wheat improvement programs of Ethiopia. In addition, three lines (MILAN/SHA7, 609/720 and MAMBA/HAR1384) having strong flour character but of which two lines had inconsistent yielding ability and one line yielding less than the general mean yield of the experiment; and five lines (Bobitcho, ETBW4311, ETBW4315, HAR3787 and Simba) of moderate to strong flour character with yielding ability above and around the grand mean were identified.
\end{abstract}

Keywords: Agronomic Performance; Bread Making Quality; Bread Wheat; GCV; PCV

\section{Introduction}

Bread wheat (Triticum aestivum) is an introduced crop in Ethiopia although the time is not known, and its demand in Ethiopia has steadily increased in the last decades (Hailu et al., 1991). It is currently cultivated as the $4^{\text {th }}$ largest cereal crop (CSA, 2002) in Ethiopia. Ethiopia is the second largest wheat producers in subSaharan Africa, next to South Africa. Bread and durum wheat in combination covers more than 1 million hectares of land in Ethiopia (Amsal et al., 2000). Estimated average yield is around 1.4 tha $^{-1}$ (CSA, 2002), which is about $31 \%$ and $48 \%$ below the average yield for Africa and the world, respectively (FAO, 2003).

The Ethiopian wheat improvement research, since its inception (1930) has focused on improving grain yield and resistance to disease except few of them were nutritional and/or processing quality oriented (Hailu et al., 1991; Amsal et al., 2000 and Solomon et al., 2000). In 1998 with response to fertilizer variations, from 10 varieties, Dashen, Galama, Megal and Abola were reported of superior in bread making quality characteristics (Solomon et al., 2000).

Screening of wheat lines of high yielding with desirable bread making quality features are a widely recognized challenging, since yield is inversely related to various aspects of grain quality, particularly to grain protein content (GPC) in cereals (Preston et al., 1992; Wrigley, 2005 a). The high GPC $[\geq 12 \%$, dry basis (db)] and gluten contents, gluten strength imparted by gluten natures (gliadins and glutenins) (Preston et. al., 1992; Gianibelli et al., 2001), grain hardness and vitreous endosperm (Ciaffi et al., 1996; Bushuk, 1998) are used in the selection for bread making quality. The GPC (weakly heritable) and gluten strength (heritable) are positively correlated to Pelshenke fermentation time (Monsivais et al., 1983), with wheat meal sedimentation volume (Payne et al., 1981; AACC, 2000) Farinogram water absorption, dough stability time and strength on over mixing, and to bread loaf volume (Lill et al., 1993; Gianibelli et al., 2001). The nature of glutenin sub-units: high molecular weight glutenin (HMW-GS) and low molecular weight glutenin (LMW-GS) fractions were factors recognized that influence dough gluten strength and quality (Gianibelli et al., 2001; Wrigley, 2005 b). Some fractions in HMW-GS were established as superior in influencing the gluten strength and thereby bread making quality (Payne et al., 1987; Belton, 1999; Gianibelli et al., 2001). Starch functionality is also equally important since starch accounts approx. $70 \%$ in wheat grain (Davis, 1994). Properties like grain hardness, baking and storage quality of wheat bread are in part influenced by the starch nature (Davis, 1994; Rahman et al., 2000). Non-sprout damaged (Hoseney, 1994) and normal (non -amylo or -waxy) starch granules (Morita et al., 2002) are preferred in bread making.

Information on the bread making quality aspect of advanced breeding lines is limited in the Ethiopian bread wheat improvement program. With the expansion of industries that process bread wheat, end use quality specification is becoming important. Therefore, the present study was conducted to identify advanced bread wheat breeding lines with good agronomic performance,

*Corresponding author. E-mail: Bultosageremew@ yahoo.com 
high grain protein content and superior dough rheological characteristics that would provide donor parents for future bread wheat improvement programs.

\section{Materials and Methods}

\subsection{Agronomic Performance}

Twenty advanced bread wheat lines were selected from five advanced national variety trials of each with twenty lines (i.e., a total of 100 lines) each comprising one local check (Pavon76) and one standard (Simba) variety. The 100 lines were grown as per the regular recommended national and regional wheat trials practices during the main cropping year of 2003/2004 in a randomized complete block design with four replications at Haramaya site adjacent to each other. From the harvested grain (2003/2004) of these 100 lines, samples (30 g) were separately milled (Tomas-Willey Laboratory Mill 4, Thomas Scientific ${ }^{\text {TM }}$, U.S.A.) to less than $1 \mathrm{~mm}$ at Haramaya University. The grain protein content [14\% moisture basis (mb)] was analyzed in duplicate by NIR spectrophotometer (Inframatic 8620 NIR, Perton, Germany). Lines (Table 1) that have average protein content greater than $10 \%$ and higher yield than the local checks were selected. In addition, high yielding lines with protein content less than $10 \%$ were also added to get enough variability.

Table 1. Pedigree, grain protein $\%$ and grain yield performance of the 20 selected bread wheat lines from 2003/04 harvest*

\begin{tabular}{|c|c|c|c|c|}
\hline Entry & Line & Pedigree & Grain protein $\%$ & $\begin{array}{l}\text { Grain yield } \\
(\mathrm{kg} / \mathrm{h})\end{array}$ \\
\hline 1 & ETBW4307 & ESTANZUELA TARARIRAS & 11.6 & 2316.0 \\
\hline 2 & ETBW4310 & TNMU/6/CEP80111/CEP1165/5/MRNG/4/YKT406/3 & 10.7 & 3589.7 \\
\hline 3 & Bobitcho & BURRLON & 10.4 & 3355.4 \\
\hline 4 & ETBW4311 & TNMU/MILAN & 10.2 & 3636.6 \\
\hline 5 & ETBW4315 & PASTOR/MUNIA/ALTAR 84 & 10.1 & 3949.1 \\
\hline 6 & ETBW4227 & RECURRENT SELECTION 1 & 10.2 & 3273.0 \\
\hline 7 & ETBW4246 & OCEP17//VEE\#5/SARA & 10.2 & 3105.0 \\
\hline 8 & MAMBA/HAR1384 & MAMBA/HAR 1348 & 12.8 & 2276.6 \\
\hline 9 & ET12D4/HAR604 & ET12D4/604 & 11.5 & 3711.7 \\
\hline 10 & RBC/HAR800 & RBC/HAR800 & 11.2 & 2679.4 \\
\hline 11 & RBC/HAR921 & RBC/HAR921 & 10.8 & 3847.5 \\
\hline 12 & MILAN/SHA7 & MILAN/SHA7 & 10.4 & 4068.4 \\
\hline 13 & HAR3787 & SUZ3/VEE\#5 & 10.6 & 3756.0 \\
\hline 14 & HAR3856 & NS732/HER//KAUZ & 10.0 & 4117.8 \\
\hline 15 & HAR3740 & HXL7573/*BAU & 7.1 & 4427.6 \\
\hline 16 & HAR/3872 & LFN/II58.57//PRL/3/HAHN & 10.6 & 3143.7 \\
\hline 17 & $609 / 720$ & HAR 604/HAR 720 & 10.1 & 2646.5 \\
\hline 18 & $604 / 719$ & HAR604/HAR719 & 9.6 & 4402.6 \\
\hline 19 & Pavon76 (local check) & VCM//CNO"S"/7C/3/CAL/BB & 9.1 & 3646.3 \\
\hline 20 & Simba (standard check) & PRINIA & 9.7 & 4480.3 \\
\hline
\end{tabular}

* Selected from 100 lines grown at Haramay which originally were from 5 advanced national yield trails of each trail with 20 lines

The twenty selected test lines were sown in the semiarid tropical belt of eastern Oromia, Ethiopia during the main growing season of 2004/2005 under rain fed conditions at two locations, namely, Haramaya University $\left[42^{\circ} 3^{\prime}\right.$ East $9^{\circ} 26^{\prime}$ North; 1980 m.a.s.l; 780 $\mathrm{mm}$ annual average rain fall; $8.25{ }^{\mathrm{O}} \mathrm{C}$ minimum and $23.4{ }^{\circ} \mathrm{C}$ maximum day temperatures] and Hirna [41 ${ }^{\circ} 4^{\prime}$ East $9^{\circ} 12$ ' North; 1870 m.a.s.l; 990-1010 mm annual average rain fall; $24{ }^{\circ} \mathrm{C}$ average for day maximum temperatures] (FAO, 1990 and AUA, 1996).

A randomized complete block design with three replications was followed at each location. Each experimental plot $(2 \mathrm{~m} \mathrm{x} 3 \mathrm{~m})$ consisted of 10 rows with $0.2 \mathrm{~m}$ spacing. Urea and DAP fertilizers were applied at the rate of $100 \mathrm{kgha}^{-1}$ each and urea was applied in split (two times). Data on number of days from planting to 50 $\%$ flowering (DTH in days) and $75 \%$ maturity (DTM in days) were recorded on plot basis. Data on other yield related traits were recorded at physiological maturity. Plant height ( $\mathrm{PH}$ in $\mathrm{cm}$ ) was recorded as average height of ten plants, tagged in each experimental plot before commencement of tillering, measured from ground level to the tip of spike, excluding awns. Thousand-kernel weight (TKW in $\mathrm{g}$ ) was determined by measuring mass of 1000 grains sampled at random. Grain yield (GY) in gplot $^{-1}$ at $12.5 \%$ moisture content was recorded and converted to $\mathrm{kgha}^{-1}$. Hectoliter weight (HLW) was determined by measuring mass of grains contained in specified volume (AACC, 2000 Method 55-10).

\subsection{Bread Making Quality}

Bread wheat grain samples $(500 \mathrm{~g})$ were taken at random from each experimental plot of test lines and milled (Perton laboratory mill 3100, Finland) for laboratory analysis at Dire Dawa Food Complex Share Company laboratory, Dire Dawa, Ethiopia. Moisture was determined by air draft drying oven by taking about $2 \mathrm{~g}$ flour samples (AACC, 2000 Method 44-15 A). Grain protein content (GPC, $14 \%, \mathrm{mb}$ ) was estimated by NIR (Inframatic 8620, Germany), (AACC, 2000 Method 39-11). Wet gluten was obtained by hand washing using dilute salt $(2 \% \mathrm{NaCl})$ solution (AACC, 2000 Method 38-10). Dried gluten (DG) was 
determined after drying wet gluten for $24 \mathrm{hrs}$ at $100{ }^{\circ} \mathrm{C}$. Pelshenke value (PV in min.)-wheat meal fermentation time test was assessed (Monsivais et al. 1983 and AACC, 2000 Method 56-50).

Dough strength was measured by Farinograph (Brabander Farinograph ${ }^{\circledR}$ E OHG, 2002, Germany) according to AACC (2000) Method 54-21 of constant dough weight method at $30 \pm 0.2{ }^{\circ} \mathrm{C}$ using a $300 \mathrm{~g}$ mixing bowel, operated at 63 revmin $^{-1}$ at the Department of Food Science and Post-harvest Technology, Haramaya University. Farinograph values: water absorption (WAB in \%), dough development time (DT in $\mathrm{min}$ ), stability time (ST in $\mathrm{min}$ ), mixing tolerance index (TI in FU) and time to breakdown (BDT in min) were evaluated by AACC method using the Farinogram software (Brabander ${ }^{\circledR}$ Farinograph version: 2.3.6, 1996-2005, Microsoft Corporation).

Data on agronomic and bread making quality traits of the three replications were analyzed using SPAR computer software for analysis of variance, mean, standard error and path analysis. Mean of the three replications were then compared $(\mathrm{p}<0.05)$ and Duncan's multiple range test (DMRT) of MSTAT C was used to evaluate the least significant difference (LSD).

\section{Results}

Yield recorded at both locations showed higher genotypic coefficient of variability (GCV) and phenotypic coefficient of variability (PCV) than yield related traits: DTH, DTM, PH, TKW and HLW (Table 2). Among the yield related traits highest GCV was recorded for TKW (Haramaya) and PH (Hirna). At both locations lowest GCV was recorded for HLW. In PCV analysis, among yield related traits TKW and HLW showed highest and lowest values, respectively, at both locations. The GPC had lowest GCV and PCV than yield and yield related traits at both locations with exceptions of DTM and HLW.

Quality characters like Pelshenke value and Farinograph parameters had high GCV and PCV than yield at both locations except WAB (Table 2). At Haramaya, stability time (ST) had highest GCV and PCV followed by Pelshenke value, BDT, TI, DT and DG. These variations were, however, low for GPC and WAB. At Hirna, ST, Pelshenke value, TI, BDT had high GCV and PCV. At this location, grain yield recorded higher GCV and PCV than DG.

The mean grain yield performance recorded at Haramaya was $4194.4 \mathrm{kgha}^{-1}$ (Table 3). The highest grain yield was recorded among lines ET12D4/HAR604, ETBW4315 and ETBW4311 ( $p>0.05$ ). The yield recorded among lines ETBW 4227, MILAN/SHA7, HAR/3872 and MAMBA/HAR1384 were the lowest. The mean GPC was $13.4 \%$. The highest GPC was for lines ETBW4310 (15.3\%), HAR/3872 (15.1\%) and Simba $(14.7 \%)(\mathrm{p}>0.05)$. The GPC in HAR3787 (11.8 $\%)$, ETBW4315 (12.1\%) and 609/720 (12.3\%) were low. The mean DG performance was $11.1 \%$. The highest DG was for lines HAR/3872 (14.9\%) followed by RBC/HAR921 (13.4\%), ETBW4310 (12.6\%) and Simba (12.4\%); and the lowest was for ETBW 4227 $(5.9 \%)$ followed by ETBW 4315 (8.7 \%) and HAR3787 $(9.3 \%)(\mathrm{p}>0.05)$. The mean Pelshenke value (PV in min.) was 73.0. The highest was recorded for lines MAMBA/HAR1384 (144.9) and ETBW4310 (144.1) (p $>0.05)$. The PV in lines ET12D4/HAR604 (27.0), ETBW 4227 (27.1), RBC/HAR921 (29.8), 604/719 (32.2) and Bobitcho (33.4) were lowest. The Farinogram WAB mean was $64.8 \%$ and the highest was for ETBW4307 (68.1\%), RBC/HAR921 (68.1\%) and HAR3856 $(67.4 \%)(\mathrm{p}>0.05)$. The lowest was for MILAN/SHA7 (59.2 \%) followed by 609/720 (61.8\%), Bobitcho (62.0 \%) and HAR3740 (62.2\%). The mean performance for DT (in min.), ST (in min.), TI (in FU) and BDT (in min.) were 3.8, 3.3, 92.9 and 5.7, respectively.

At Hirna, the mean grain yield was $4421.0 \mathrm{kgha}^{-1}$ (Table 4).

The yield recorded by ETBW4307 and 609/720 was the lowest. The mean GPC was $14.1 \%$. The highest GPC was recorded for HAR/3872 (15.4 \%), ETBW4310 $(15.0 \%)$ and RBC/HAR921 (14.9\%) and the lowest was for 609/720 (11.9\%) followed by HAR3787 (13.3 $\%)$ and ETBW4315 (13.5\%). The mean DG performance was $12.2 \%$. The highest DG was for HAR/3872 (14.6 \%), RBC/HAR921 (14.4\%), 604/719 (13.9\%), Bobitcho (13.7\%) and HAR3856 (13.7\%) (p $>0.05$ ). The DG level in lines 609/720 (9.7\%), ETBW $4227(10.5 \%)$ and ETBW $4315(10.5 \%)$ were low (p > $0.05)$.

The mean PV at Hirna was 70.1 min. The highest was recorded in Simba (144.0), ETBW4310 (139.7)and RBC/HAR800 (136.7) and the lowest was in lines ETBW4227 (26.8) and RBC/HAR921 (27.0) ( $\mathrm{p}>0.05)$. The mean performance of WAB was $65.3 \%$. The highest was for HAR3856 (69.4\%), followed by RBC/HAR921 (68.1\%), ETBW4227 (67.4\%) and ETBW4246 (67.4 \%). The lowest was for MILAN/SHA7 (60.3\%) followed by ET12D4/HAR604 $(61.5 \%), 609 / 720(62.2 \%)$ and HAR3740 (63.0 \%). The mean performance for DT (in min.), ST (in min.), TI (in FU) and BDT (in min.) were 3.7, 3.6, 89.1 and 5.9 , respectively. The DT for lines MAMBA/HAR1384 and RBC/HAR800 were different $(\mathrm{p}<0.05)$ from the rest of the lines at the respective locations (Tables 3 and $4)$. These two lines appeared also strong flour lines (Figure 1).

The DT for lines ETBW4227, HAR/3872, RBC/HAR921 and ET12D4/HAR604 were shortest (p $>0.05)$ at the respective sites. The ST for RBC/HAR800, MAMBA/HAR1384 and MILAN/SHA7 appeared superior $(\mathrm{p}>0.05)$ at the respective sites. 
Table 2. Range, mean, genotypic and phenotypic coefficient variabilities of 14 traits of 20 wheat lines grown at Haramaya and Hirna

\begin{tabular}{|c|c|c|c|c|c|c|c|c|c|}
\hline \multicolumn{6}{|c|}{ Haramaya } & \multicolumn{4}{|l|}{ Hirna } \\
\hline No. & Trait & Range & Mean \pm S.E. & GCV & PCV & Range & Mean \pm S.E. & GCV & PCV \\
\hline 1 & Days to heading (DTH) (day) & $55.0-71.0$ & $63.2 \pm 2.0$ & 6.8 & 7.8 & $56.0-78.7$ & $67.6 \pm 1.2$ & 10.1 & 10.4 \\
\hline 2 & Days to maturity (DTM) (day) & $104.3-124.0$ & $114.1 \pm 2.7$ & 4.2 & 5.1 & $106.0-125.7$ & $115.2 \pm 2.8$ & 4.6 & 5.5 \\
\hline 3 & Plant height $(\mathrm{PH})(\mathrm{cm})$ & $88.1-119.8$ & $102.5 \pm 5.7$ & 6.9 & 9.7 & $83.9-120.0$ & $101.5 \pm 4.1$ & 10.2 & 11.3 \\
\hline 4 & 1000 kernel weight $(\mathrm{TKW})(\mathrm{g})$ & $33.2-44.0$ & $37.7 \pm 1.9$ & 8.4 & 10.4 & $31.5-44.8$ & $37.6 \pm 2.8$ & 6.9 & 11.4 \\
\hline 5 & Hectoliter weight (HLW) (g/L) & $748.1-828.5$ & $799.1 \pm 14.0$ & 1.8 & 2.8 & $757.9-832.1$ & $807.6 \pm 16.1$ & 1.8 & 3.1 \\
\hline 6 & Grain yield $(\mathrm{GY})(\mathrm{kg} / \mathrm{h})$ & $3426-5581$ & $4194.4 \pm 349.0$ & 12.4 & 16.0 & $3134-5643$ & $4421.0 \pm 600.3$ & 13.2 & 21.2 \\
\hline 7 & Grain protein content (GPC) $(\%)$ & $11.8-15.3$ & $13.4 \pm 0.7$ & 6.3 & 9.0 & $11.9-15.4$ & $14.1 \pm 0.5$ & 4.7 & 6.6 \\
\hline 8 & Dried gluten (DG) $(\%)$ & $5.9-14.9$ & $11.1 \pm 1.3$ & 14.6 & 20.1 & $9.7-14.6$ & $12.2 \pm 1.0$ & 10.0 & 13.9 \\
\hline 9 & Pelshenke value (PV) (min) & $27.0-144.9$ & $73.0 \pm 3.8$ & 57.5 & 57.9 & $26.8-144.0$ & $70.1 \pm 11.1$ & 60.5 & 63.5 \\
\hline 10 & $\begin{array}{l}\text { Farinograph water absorption } \\
(\mathrm{WAB})(\%)\end{array}$ & $59.2-68.1$ & $64.8 \pm 1.1$ & 3.3 & 3.8 & $60.3-7.4$ & $65.3 \pm 0.8$ & 3.3 & 3.6 \\
\hline 11 & Development time (DT) (min) & $1.8-7.8$ & $3.8 \pm 0.4$ & 38.3 & 39.9 & $1.5-6.5$ & $3.7 \pm 0.4$ & 35.6 & 37.5 \\
\hline 12 & Stability time (ST) (min) & $1.0-9.6$ & $3.3 \pm 0.7$ & 67.6 & 72.8 & $0.8-9.1$ & $3.6 \pm 0.7$ & 60.6 & 64.6 \\
\hline 13 & Tolerance index (TI) (FU) & $29.0-198.3$ & $92.9 \pm 15.2$ & 49.6 & 53.5 & $23.0-217.0$ & $89.1 \pm 16.8$ & 56.7 & 61.2 \\
\hline 14 & Breakdown time (BDT) (min) & $2.3-12.3$ & $5.6 \pm 1.2$ & 49.1 & 55.9 & $1.9-12.6$ & $5.9 \pm 1.0$ & 52.1 & 56.4 \\
\hline
\end{tabular}

$G C V=$ genotypic coefficient of variation, $P C V=$ phenotypic coefficient of variation, S. E. $=$ standard error 
Table 3. The mean values of six agronomic and eight bread making quality characters for 20 bread wheat lines grown at Haramaya

\begin{tabular}{|c|c|c|c|c|c|c|c|c|c|c|c|c|c|c|}
\hline \multirow[b]{2}{*}{ Genotype/Line } & \multicolumn{6}{|c|}{ Agronomic traits } & \multicolumn{8}{|c|}{ Bread making quality traits } \\
\hline & $\mathrm{DTH}_{\text {(day) }}$ & DTM(day) & $\mathrm{PH}(\mathrm{cm})$ & TKW $(g)$ & HLW (g/L) & $\mathrm{GY}_{(\mathrm{kg} / \mathrm{h})}$ & $\mathrm{GPC}(\%)$ & $\mathrm{DG}(\%)$ & $\mathrm{PV}(\min )$ & WAB (\%) & DT (min) & $\mathrm{ST}(\mathrm{min})$ & $\mathrm{TI}(\mathrm{FU})$ & $\mathrm{BDT}(\mathrm{min})$ \\
\hline ETBW4307 & 62.3 & 115.3 & 119.8 & 44.0 & 798.6 & 4068 & 13.8 & 11.6 & 43.7 & 68.1 & 2.9 & 2.3 & 120.7 & 3.8 \\
\hline ETBW4310 & 69.0 & 120.0 & 94.0 & 36.1 & 823.4 & 3947 & 15.3 & 12.6 & 144.1 & 66.3 & 4.0 & 3.0 & 97.3 & 5.0 \\
\hline Bobitcho & 64.3 & 118.7 & 106.8 & 34.7 & 796.5 & 4066 & 13.4 & 11.9 & 33.4 & 62.0 & 2.9 & 2.6 & 90.0 & 4.1 \\
\hline ETBW4311 & 60.3 & 111.0 & 100.5 & 40.3 & 828.5 & 4853 & 14.0 & 11.6 & 96.4 & 65.0 & 4.1 & 3.3 & 80.3 & 5.3 \\
\hline ETBW4315 & 60.3 & 109.3 & 95.1 & 36.2 & 801.9 & 4886 & 12.1 & 8.7 & 91.2 & 63.2 & 4.6 & 2.8 & 76.0 & 6.2 \\
\hline ETBW4227 & 65.0 & 114.3 & 103.5 & 33.8 & 748.1 & 3426 & 13.6 & 5.9 & 27.1 & 65.1 & 1.8 & 1.0 & 198.3 & 2.3 \\
\hline ETBW4246 & 61.0 & 113.0 & 102.7 & 42.8 & 810.2 & 4075 & 13.9 & 11.3 & 113.7 & 66.2 & 3.4 & 1.9 & 111.0 & 4.4 \\
\hline MAMBA/HAR 1384 & 68.7 & 117.3 & 98.4 & 33.2 & 796.0 & 3634 & 13.2 & 10.3 & 144.9 & 65.4 & 7.8 & 9.6 & 35.0 & 12.3 \\
\hline ET12D4/HAR604 & 63.0 & 108.3 & 107.9 & 37.5 & 780.3 & 5581 & 12.7 & 11.3 & 27.0 & 63.8 & 2.1 & 1.6 & 110.3 & 3.1 \\
\hline RBC/HAR800 & 68.7 & 116.7 & 103.8 & 33.6 & 791.0 & 3923 & 14.4 & 11.6 & 135.3 & 65.8 & 6.0 & 9.3 & 33.3 & 10.5 \\
\hline RBC/HAR921 & 61.7 & 114.0 & 106.7 & 35.0 & 799.2 & 3663 & 13.9 & 13.4 & 29.8 & 68.1 & 2.1 & 1.3 & 180.0 & 2.5 \\
\hline MILAN/SHA7 & 67.0 & 122.7 & 98.5 & 34.1 & 808.4 & 3491 & 12.4 & 10.2 & 79.0 & 59.2 & 4.8 & 5.0 & 29.0 & 11.5 \\
\hline HAR3787 & 60.0 & 115.0 & 101.9 & 41.7 & 788.3 & 4764 & 11.8 & $9.3 \mathrm{~d}$ & 49.8 & 64.8 & 3.8 & 2.5 & 73.3 & 5.3 \\
\hline HAR3856 & 62.0 & 111.3 & 110.0 & 39.5 & 808.2 & 4483 & 12.7 & 11.2 & 47.7 & 67.4 & 3.3 & 2.4 & 121.0 & 4.2 \\
\hline HAR3740 & 69.0 & 117.3 & 96.4 & 40.2 & 777.0 & 4252 & 12.8 & 10.8 & 48.6 & 62.2 & 4.8 & 3.6 & 51.5 & 6.9 \\
\hline HAR/3872 & 71.0 & 124.0 & 108.2 & 36.5 & 800.5 & 3593 & 15.1 & 14.9 & 50.4 & 66.0 & 2.0 & 1.6 & 163.0 & 2.6 \\
\hline 609/720 & 61.7 & 112.0 & 94.8 & 39.2 & 795.3 & 4671 & 12.3 & 11.0 & 46.2 & 61.8 & 4.4 & 3.8 & 46.7 & 7.4 \\
\hline $604 / 719$ & 55.0 & 109.7 & 118.6 & 42.8 & 812.8 & 3911 & 13.4 & 11.8 & 32.2 & 65.1 & 2.7 & 2.7 & 86.0 & 3.8 \\
\hline Pavon76 & 58.0 & 107.0 & 94.1 & 35.0 & 816.8 & 4791 & 12.7 & 9.9 & 87.0 & 64.1 & 4.7 & 3.8 & 61.5 & 6.6 \\
\hline Simba & 56.3 & 104.3 & 88.1 & 37.1 & 800.4 & 3813 & 14.7 & 12.4 & 133.2 & 65.8 & 3.6 & 2.7 & 93.3 & 4.8 \\
\hline Mean & 63.2 & 114.2 & 102.5 & 37.7 & 799.1 & 4194.4 & 13.4 & 11.1 & 73.0 & 64.8 & 3.8 & 3.3 & 92.9 & 5.7 \\
\hline $\mathrm{SE} \pm$ & 2.0 & 2.7 & 5.7 & 1.9 & 14.0 & 349.0 & 0.7 & 1.3 & 3.8 & 1.1 & 0.4 & 0.7 & 15.2 & 1.2 \\
\hline CV\% & 3.8 & 2.9 & 6.8 & 6.2 & 2.1 & 10.2 & 6.5 & 13.9 & 6.3 & 2.0 & 11.4 & 27.1 & 20.1 & 26.7 \\
\hline $\operatorname{LSD}(0.05)$ & 4.0 & 5.4 & 3.4 & 3.9 & 28.2 & 706.5 & 1.4 & 2.5 & 7.6 & 2.1 & 0.7 & 1.5 & 30.8 & 2.5 \\
\hline
\end{tabular}

Where: DTH=days to heading, DTM=days to maturity, $P H=$ plant height, $T K W=$ thousand kernel weight, $H L W=$ hectoliter weight, GY=grain yield, GPC=grain protein content, DG=dried gluten percentage, $P V=$ Pelshenke value, WAB= frarinogram water absorp 
Table 4. The mean values of six agronomic and eight bread making quality characters for 20 bread wheat lines grown at Hirna

\begin{tabular}{|c|c|c|c|c|c|c|c|c|c|c|c|c|c|c|}
\hline \multirow[b]{2}{*}{ Genotype/Line } & \multicolumn{6}{|c|}{ Agronomic traits } & \multicolumn{8}{|c|}{ Bread making quality traits } \\
\hline & DTH (day) & DTM (day) & $\mathrm{PH}(\mathrm{cm})$ & TKW(g) & HLW (g/L) & GY $(\mathrm{kg} / \mathrm{h})$ & GPC (\%) & DG $(\%)$ & $\mathrm{PV}(\min )$ & WAB (\%) & $\mathrm{DT}(\min )$ & $\mathrm{ST}(\mathrm{min})$ & TI (FU) & BDT (min) \\
\hline ETBW4307 & 68.7 & 115.7 & 120.0 & 41.0 & 811.4 & 3134 & 14.5 & 11.9 & 53.5 & 66.3 & 3.6 & 3.1 & 74.3 & 5.0 \\
\hline ETBW4310 & 75.7 & 125.7 & 97.1 & 35.4 & 832.1 & 4506 & 15.0 & 12.1 & 139.7 & 65.8 & 3.5 & 2.6 & 104.7 & 4.4 \\
\hline Bobitcho & 67.3 & 116.3 & 104.7 & 35.2 & 795.7 & 4644 & 14.2 & 13.7 & 31.1 & 63.5 & 3.2 & 2.9 & 77.7 & 4.7 \\
\hline ETBW4311 & 65.3 & 116.0 & 94.4 & 37.3 & 822.0 & 4218 & 13.8 & 10.7 & 96.7 & 65.2 & 4.4 & 3.3 & 81.0 & 5.5 \\
\hline ETBW4315 & 65.0 & 109.3 & 88.2 & 36.8 & 824.1 & 3954 & 13.5 & 10.5 & 100.9 & 65.7 & 4.7 & 4.5 & 68.3 & 6.6 \\
\hline ETBW4227 & 67.0 & 115.0 & 104.6 & 34.1 & 778.6 & 3808 & 14.5 & 10.5 & 26.8 & 67.4 & 1.51 & 0.8 & 217.0 & 1.9 \\
\hline ETBW4246 & 66.7 & 113.0 & 97.4 & 44.8 & 821.9 & 3626 & 13.7 & 12.0 & 117.4 & 67.4 & 4.0 & 2.7 & 103.0 & 5.1 \\
\hline MAMBA/HAR1384 & 76.7 & 120.3 & 98.1 & 32.2 & 798.1 & 3559 & 14.4 & 11.2 & 112.4 & 65.2 & 6.1 & 8.4 & 30.3 & 11.2 \\
\hline ET12D4/HAR604 & 67.3 & 112.3 & 106.4 & 37.1 & 792.0 & 5433 & 13.7 & 13.0 & 29.1 & 61.5 & 2.2 & 2.1 & 97.0 & 3.4 \\
\hline RBC/HAR800 & 76.7 & 122.0 & 100.6 & 31.5 & 797.0 & 4328 & 14.5 & 11.8 & 136.7 & 64.9 & 6.5 & 9.1 & 29.0 & 11.8 \\
\hline RBC/HAR921 & 62.0 & 110.0 & 115.8 & 38.2 & 810.8 & 4776 & 14.9 & 14.4 & 27.0 & 68.1 & 1.9 & 1.2 & 185.0 & 2.3 \\
\hline MILAN/SHA7 & 73.3 & 121.3 & 111.1 & 39.3 & 828.1 & 5344 & 13.6 & 12.0 & 35.5 & 60.3 & 4.7 & 7.4 & 23.0 & 12.6 \\
\hline HAR3787 & 64.0 & 112.7 & 96.3 & 38.8 & 796.6 & 4795 & 13.3 & 10.9 & 42.0 & 65.9 & 3.6 & 3.4 & 76.7 & 5.1 \\
\hline HAR3856 & 61.3 & 108.0 & 106.8 & 41.3 & 819.2 & 5302 & 14.6 & 13.7 & 50.6 & 69.4 & 3.0 & 2.3 & 125.3 & 3.7 \\
\hline HAR3740 & 76.0 & 120.3 & 95.1 & 39.1 & 798.9 & 4805 & 13.7 & 13.0 & 47.4 & 63.0 & 4.5 & 3.6 & 50.3 & 6.8 \\
\hline $\mathrm{HAR} / 3872$ & 78.7 & 124.0 & 113.8 & 38.6 & 815.1 & 4244 & 15.4 & 14.6 & 31.6 & 66.3 & 1.91 & 1.4 & 169.3 & 2.5 \\
\hline $609 / 720$ & 70.3 & 115.7 & 93.0 & 34.9 & 757.9 & 3371 & 11.9 & 9.7 & 41.1 & 62.2 & 5.2 & 4.4 & 36.3 & 10.2 \\
\hline $604 / 719$ & 56.0 & 112.7 & 119.0 & 41.7 & 829.2 & 4002 & 14.4 & 13.9 & 34.1 & 65.7 & 2.6 & 2.8 & 88.3 & 4.0 \\
\hline Pavon76 & 57.7 & 108.0 & 84.0 & 36.8 & 805.3 & 4929 & 14.0 & 12.3 & 103.7 & 65.4 & 3.9 & 3.5 & 66.0 & 5.6 \\
\hline Simba & 57.0 & 106.0 & 83.9 & 38.4 & 818.4 & 5643 & 14.3 & 12.4 & 144.0 & 65.9 & 3.8 & 2.8 & 79.3 & 5.4 \\
\hline Mean & 67.6 & 115.2 & 101.5 & 37.6 & 807.6 & 4421.0 & 14.1 & 12.2 & 70.1 & 65.3 & 3.7 & 3.6 & 89.1 & 5.9 \\
\hline $\mathrm{SE} \pm$ & 1.2 & 2.8 & 4.1 & 2.8 & 16.1 & 600.3 & 0.5 & 0.9 & 11.1 & 0.8 & 0.4 & 0.7 & 16.8 & 1.0 \\
\hline $\mathrm{CV} \%$ & 2.1 & 3.0 & 4.9 & 9.0 & 2.4 & 16.6 & 4.7 & 9.7 & 19.4 & 1.5 & 11.8 & 22.4 & 23.1 & 21.5 \\
\hline $\operatorname{LSD}(0.05)$ & 2.4 & 5.6 & 8.3 & 5.6 & 32.5 & 1215 & 1.1 & 2.0 & 22.4 & 1.6 & 0.7 & 1.3 & 34.0 & 2.1 \\
\hline
\end{tabular}

Where: DTH, DTM, PH, TKW, HLW, GY, GPC, DG, PV,WAB, DT, ST, TI, BDT, SE, CV and LSD are as given in Table 3. 

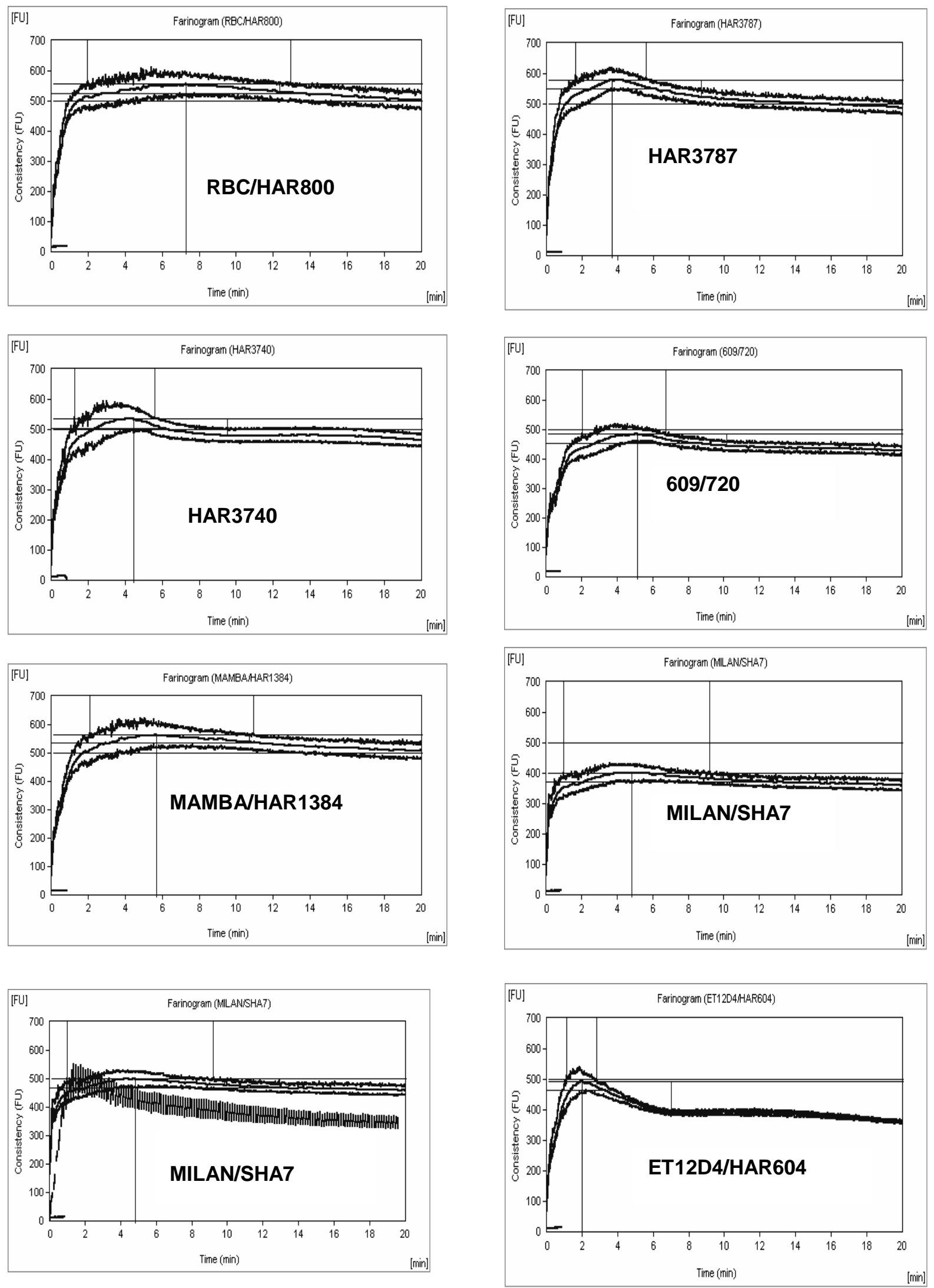

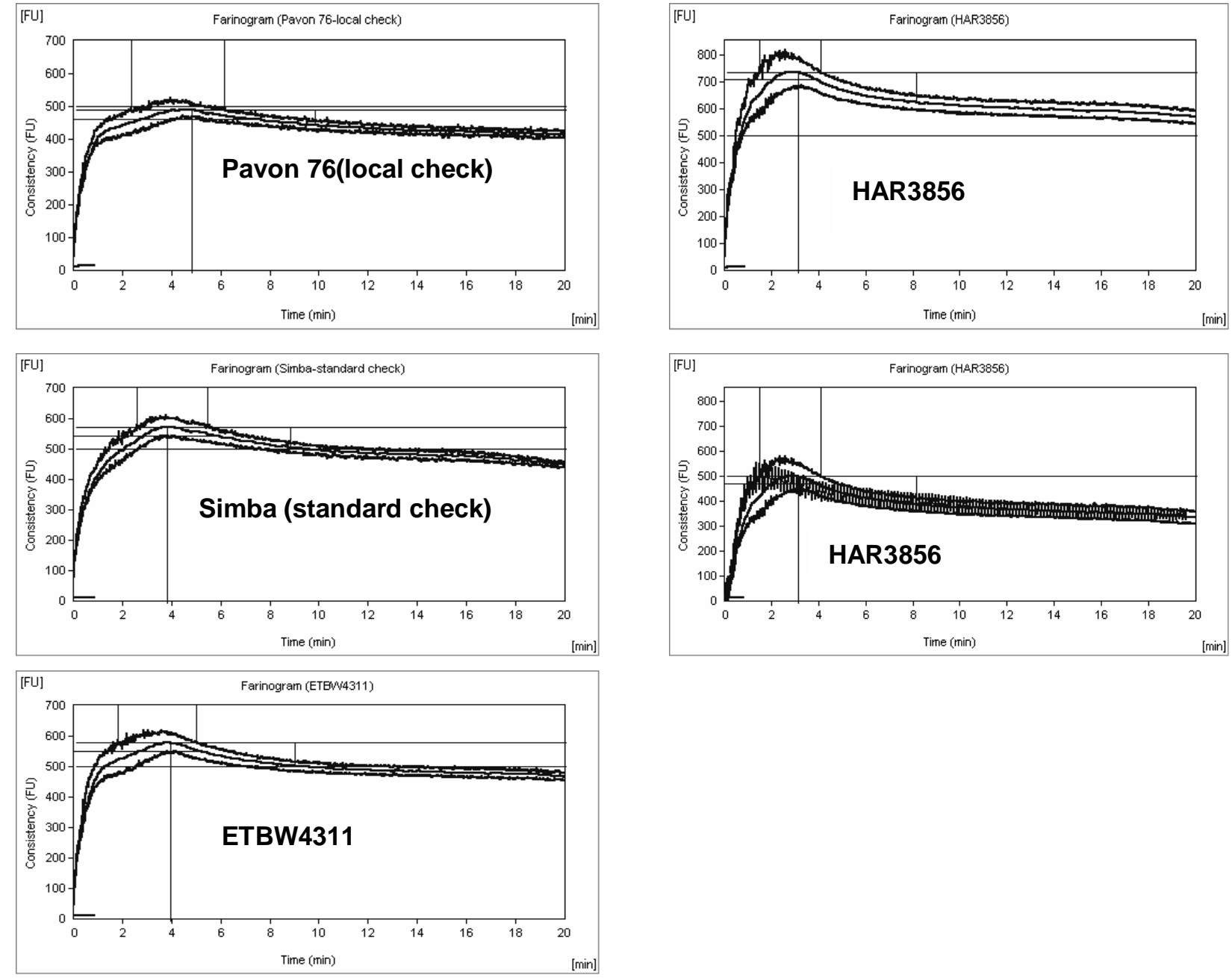

Fig. 1. Selected Farinograms for strong (RBC/HAR800, HAR3740, MAMBA/HAR1384, HAR3787, 609/720 and MILAN/SHA7), moderate (Pavon76, Simba and ETBW 4311) and weak (ET12D4/HAR604 and HAR3856) flour lines

The shortest ST was performed by ETBW4227, RBC/HAR921, ET12D4/HAR604 and HAR/3872, at the respective locations. The small TI (i.e., the smallest TI, the strong the flour is likely to be) was recorded for MILAN/SHA7, RBC/HAR800 and MAMBA/HAR1384 followed by $609 / 720$ and HAR3740 at the respective locations $(\mathrm{p}>0.05)$. Their BDT are also high at the respective locations; and these lines showed a characteristic of strong flour (Figure 1). The TI in lines ETBW4227, RBC/HAR921, HAR/3872, ET12D4/HAR604 and ETBW4246 were highest and apparently these lines showed a characteristic of weak flour (Tables 3 and 4).

\section{Discussion}

The estimates of GCV and PCV at both locations showed that most quality characters, except GPC, WAB and HLW, had high variability as compared to yield and yield related characters (Tables 2, 3 and 4). The small variability observed in GPC is because under uniform fertilizer applications and almost similar growing and drying conditions, the apparent variability in GPC (weakly heritable) is minimal and GPC is positively correlated with WAB and HLW (Bushuk, 1998; Ermias, 2005). Yield being influenced by a number of factors has been negatively correlated with various grain quality aspects, particularly with GPC (Preston et al., 1992; Peterson at al., 1992). In 2003/2004, the high yielding lines (Simba, HAR3740, 604/719, HAR3856, MILAN/SHA7) had small GPC and vice versa (MAMBA/HAR1384 and ETBW4307) (Table 1). The correlation studied among the characters also revealed similar facts - at Haramaya site, yield of the lines showed significant $(\mathrm{p}<0.01)$ negative correlation with GPC, and also weakly at Hirna (results not presented) (Ermias, 2005). The high yielding lines (ET12D4/HAR604 and HAR3787) were small in GPC and vice versa (RBC/HAR800 and HAR/3872) at the respective locations (Tables 3 and 4). The grain yield in line MAMBA/HAR1384 appeared low (Tables 1, 3 and 4). The highest grain yield for Simba in 2003/2004 reduced at 
Haramaya site in 2004/2005. The GPC in HAR3740 in $2003 / 2004$ was the least (Table 1) and in 2004/2005 had substantially increased, eventhough remained below grand mean (Tables 3 and 4). Lines ETBW4311, MAMBA/HAR1384, RBC/HAR800, MILAN/SHA7, HAR3787, HAR3740, 609/720, Pavon76 and Simba showed a characteristic of strong flour (high gluten strength or small TI) at the respective locations (Tables 3 and 4). This indicates, the recognized strong genetic expression for the gluten strength (Peterson at al., 1992; Gianibelli et al., 2001; Wrigley, 2005 b). Thus, in the present material, in spite of low variability for yield related characters, there was a scope to identify plausible donors for rheological quality traits as strong, normal or moderate and weak wheat flour lines.

Protein and gluten contents, Farinogram flour dough characters and high Pelshenke times are used to assess quality of bread wheat in the selection (MacRitchie, 1984; Dobraszczyk, 2004). An increase in \%protein in the grain was positively correlated with bread loaf volume (Finney and Barmore, 1990; He and Hoseney, 1992; Dobraszczyk, 2004). A Farinogram of good bread making flour takes longer times to reach its maximum and shows minimum degree of softening on over mixing, whereas weak flour produces a Farinogram that rises rapidly and decreases rapidly on over mixing. Farinogram high water absorption, long dough development time, long stability time and small degree of weakening on over-mixing (i.e., small TI) are known to be positively correlated with large bread loaf volume (Lill et al., 1993; Dobraszczyk, 2004). In this study, lines RBC/HAR800, HAR3740 and Pavon76 were superior in bread making features i.e., strong flour characteristic (Figure 1) at both locations and their yield also appeared around grand mean (Tables 3 and 4). Lines MILAN/SHA7, 609/720 and MAMBA/HAR1384 showed a character of strong flour, but the yielding ability of MILAN/SHA7 and 609/720 appeared inconsistent (over two environments in 2004/2005) and that of MAMBA/HAR1384 appeared less than grand mean at both locations. Bobitcho, ETBW4311, ETBW4315, HAR3787 and Simba appeared to possess characteristics of moderate strong flour, and their yielding performance at both locations was inconsistent except that of HAR3787, which appeared superior.

The ET12D4/HAR604 and HAR3856 lines performed superior in yielding ability at both locations, but showed characteristics of weak flours. The yield in lines RBC/HAR921, ETBW4310 and HAR/3872 appeared inconsistent at both locations and showed characteristics of weak flour. The yield of lines ETBW4246 and ETBW4227 (weak flour); and ETBW4307 and 604/719 (moderately weak flour) appeared less than the grand mean at both locations. Even though in lines ETBW4227, HAR/3872, RBC/HAR921, ETBW4246 and ET12D4/HAR604, protein contents are above $11 \%$, flour strength appeared weak because dough strength is influenced not only by high protein content but also is by the gluten nature (Preston et al., 1992; Anjum and Walker, 2000 and Dobraszczyk, 2004).

In conclusion, this study had furnished the following information: lines RBC/HAR800, HAR3740, MAMBA/HAR1384, 609/720, MILAN/SHA7 and Pavon76, which were superior in bread making quality parameters with yield around grand mean could be considered for release, where the objective is superior bread-making quality (Tables 3 and 4, Figure 1). However, lines MILAN/SHA7, and 609/720 (inconsistent yielding) and MAMBA/HAR1384 (low grain yielding at both sites) need further investigation at different agro-ecological areas to assess their potential for yield and bread making quality. These six lines could also serve as good donor source in bread wheat improvement breeding programs in Ethiopia. HAR3787, Bobitcho, ETBW4311, ETBW4315 and Simba showed moderate to strong flour characteristics and their yield in some cases was superior (HAR3787) and in some appeared inconsistent but is around the grand mean. These can also serve as donor parents in the future bread wheat improvement program. Lines ET12D4/HAR604, HAR3856, RBC/HAR921 and HAR/3872 appeared a characteristics of weak flour and their yield in some cases is superior (ETBW 4310, ET12D4/HAR604 and HAR3856) and in some appeared inconsistent (ETBW 4310, RBC/HAR921 and HAR/3872), hence these lines can be used as a future donor for bread wheat breeding programs intended for soft wheat products (cookies and cakes).

\section{Acknowledgement}

Research expense and fellowship support made by ATVET program of the federal ministry of agriculture and study permit to Mr. Ermias Estifanos by Haramaya University are sincerely indebted. Dire Dawa Food complex share company is sincerely acknowledged for laboratory grain milling service.

\section{References}

AACC (American Association of Cereal Chemists). 2000. Approved Methods of the American Association of Cereal Chemists, $10^{\text {th }}$ ed. American Association of Cereal Chemists. St. Paul, MN.

Amsal, T. Labuschagne, M. T. and Maartens, H. 2000. Identification of Ethiopian wheat cultivars by seed storage protein electrophoresis.The Eleventh Regional Wheat Workshop for Eastern, Central and Southern Africa. Addis Ababa, Ethiopia: CIMMYT. pp. 49-59.

Anjum, F. M. and Walker, C. E. 2000. Grain, flour and bread-making properties of eight Pakistani hard white spring wheat cultivars grown at three different locations for 2 years. International Journal of Food Science and Technology 35: 407-416.

AUA (Alemaya University of Agriculture). 1996. Proceedings of the $13^{\text {th }}$ Annual Research and 
Extension Review Meeting. Alemaya University of Agriculture, 26-28 February 1996, Alemaya, Ethiopia.

Belton, P. S. 1999. Mini review: on the elasticity of wheat gluten. Journal of Cereal Science 29: 103-107

Brabender ${ }^{\circledR}$ OHG. 2002. Brabender Measurement and Control Systems: Instruction Manual for Brabender ${ }^{\circledR} E$ with USB port. Brabender OHG, Duisburg, Germany.

Bushuk, W. 1998. Wheat breeding for end-product use. Euphytica 100: 137-145

Ciaffi, M. Tozzi, L. and Lafiandra, D. 1996. Relationship between flour protein composition determined by size-exclusion high pressure liquid chromatography and dough rheological parameters. Cereal Chemistry 73: 346-351

CSA (Central Statistical Authority). 2002. Crop Production For-cast Sample Survey. Report on For-cast of Area and Production of Major Crops (for Rural Private Peasant Holdings). Statistical Bulletin 271: 18-19.

Davis, E. A. 1994. Wheat starch. Cereal Foods World 39: $34-36$

Dobraszczyk, B. J. 2004. Wheat: dough rheology. In: C. Wrigley, H. Corker and C. E. Walker (eds.). Encyclopedia of Grain Science. Vol. 3, Elsevier Ltd., Oxford, UK. pp. 400-416

Ermias, E. 2005. Assessment for Quality Traits, Yield and Yield Related Characters in Advanced Ethiopian Bread Wheat (Triticum aestivum L.) Breeding Lines. M.Sc. Thesis. Alemaya University, Ethiopia

FAO (Food and Agriculture Organization of the United Nations). 1990. Agrometerology Group, Remote Sensing Center. Research and Technology Division. Rome, Italy. p.120.

FAO (Food and Agriculture Organization of the United Nations). 2003. FAO Statistic Series, Vol. 57 No 177. Rome, Italy.

Finney K. F. and Barmore M. A. 1990. Loaf volume and protein content of hard winter and spring wheats. Cereal Foods World 35: 291-312

Gianibelli, M. C., Larroque, O. R. MacRitchie, F. and Wrigley, C. W. 2001. Biochemical, genetic and molecular characterization of wheat endosperm proteins. Cereal Chemistry 78: 635-646

Hailu, G. M. Tanner, D. G. and Mengistu, H. 1991. Bread Wheat Breeding and Genetics Research in Ethiopia: A Historical Perspective, Addis Ababa, IAR/CIMMYT.

He, H. and Hoseney, R.C. 1992. Effect of the quantity of wheat flour protein on bread loaf volume. Cereal Chemistry 69: 17-19.

Hoseney, R. C. 1994. Principles of Cereal Science and Technology. 2nd. ed., American Association of Cereal Chemists. St. Paul, MN.

Lill, D. V., Wentzel, B.S. ,Smith, M.F. and Villiers, O. T. 1993. Comparison of protein extraction procedures to assess the effect of quantitative protein composition on the bread-making quality of South African winter wheat cultivars. South African Journal of Plant and Soil 10: 162-167

MacRitchie, F.1984. Baking quality of wheat flours. Advanced Food Research 29: 201-277

Monsivais, M., Hoseney, R. C. and Finney, K. F. 1983. The Pelshenke test and its value in estimating bread-making properties of hard winter wheats. Cereal Chemistry 60: 51-55

Morita, N., Maeda, T., Miyazaki, M., Yamamori, M., Miura, H. and Ohtsuka, I. 2002. Dough and baking properties of high-amylose and waxy wheat flours. Cereal Chemistry 79:491-495

Peterson, C. J., Graybosch, R.A., Baenziger, P. S. and Grombacher, A. W. 1992. Genotype and environment effects on quality characteristics of hard red winter wheat. Crop Science 32: 98-103

Preston, K. R., Lukow, O. M. and Morgan, B. 1992. Analysis of relationships between flour quality properties and protein fractions in a world wheat collections. Cereal Chemistry 69: 560-567

Payne, P. I., Nightingale, M. A., Krattiger, A. F. and Holt, L. M. 1987. The relationship between HMW glutenin subunit composition and the breadmaking quality of British-grown wheat varieties. Journal of the Science of Food and Agriculture 40:51-65

Payne, P. I., Holt, L. M. and Law, C. N. 1981. Structure and genetic studies on the high-molecular-weight subunits of wheat glutenin. I. Allelic variation in subunits amongst varieties of wheat (Triticum aestivum).Theoretical and Applied Genetics 60:229-236

Rahman, S. Li, Z. Batey, I. Cochrane, M. P. Appels, R. and Morell, M. 2000. Genetic alteration of starch functionality in wheat. Journal ofCereal Science 31: $91-110$

Solomon, G., Desalegn, D., Bedada, G., Payne, T. S., Zewdie A. and Balcha, Y. 2000. Milling and baking quality of Ethiopian bread wheat cultivars. The Eleventh Regional Wheat Workshop for Eastern, Central and Southern Africa. Addis Ababa, Ethiopia: CIMMYT. pp. 87-96.

Wrigley, C. 2005 a. Precision agriculture-a means of improving grain quality. Cereal Foods World 50: $143-144$

Wrigley, C. 2005b. Grain protein composition -Repeated cycles of research on dough quality. Cereal Foods World 50: 38-40 